\title{
Navicordulia aemulatrix sp. nov. (Odonata, Corduliidae) from northeastern Santa Catarina State, Brazil
}

\author{
Ângelo Parise Pinto ${ }^{1,2} \&$ Carlos José Einicker Lamas ${ }^{1}$
}

\begin{abstract}
${ }^{1}$ Museu de Zoologia, Universidade de São Paulo, Av. Nazaré 481, Ipiranga 04263-000 São Paulo-SP, Brazil. odonata_angelo@hotmail.com; einicker@usp.br ${ }^{2}$ Programa de Pós-graduação em Ciências Biológicas (Zoologia), Instituto de Biociências, Universidade de São Paulo, São Paulo-SP, Brazil; Collaborator researcher in the Laboratório de Biologia e Sistemática de Odonata, Departamento de Entomologia, Museu Nacional, Universidade Federal do Rio de Janeiro, Rio de Janeiro-RJ, Brazil.
\end{abstract}

\begin{abstract}
Navicordulia aemulatrix sp. nov. (Odonata, Corduliidae) from northeastern Santa Catarina State, Brazil. Navicordulia aemulatrix sp. nov. (holotype male deposited in MZSP: Brazil, Santa Catarina State, [São Bento do Sul municipality, 26 $14^{\prime} 58^{\prime \prime}$,S, 49 22'59'W], [railroad station] Rio Vermelho, II.1952) is described and illustrated based on three males. The long cercus (2.9-3.2 $\mathrm{mm}$ ) places this species in the longistyla-group together with $N$. kiautai, $N$. longistyla and $N$. nitens but it differs from them mainly by the shape of cercus, with carinated part occupying 0.33 of cercus total length, and also by dorsal, ventro-medial and ventrolateral tubercles developed. An unusual process on tergal portion of prothorax is reported for the first time in Navicordulia. The rate of description of new species of South American 'Corduliidae' is discussed. A map with records of Atlantic Forest Navicordulia species and a list of Brazilian corduliids by state are also presented.
\end{abstract}

KEYWORDS. Anisoptera; Corduliinae; dragonfly; morphology; taxonomy.

RESUMO. Navicordulia aemulatrix sp. nov. (Odonata, Corduliidae) do nordeste do estado de Santa Catarina, Brasil. Navicordulia aemulatrix sp. nov. (holótipo macho depositado no MZSP: Brasil, estado de Santa Catarina, [município de São Bento do Sul, $26^{\circ} 14^{\prime} 58^{\prime \prime}$ S, 49²2'59'W], [estação ferroviária] Rio Vermelho, II.1952) é descrita e ilustrada com base em três machos. O cerco longo (2,9-3,2 mm), posiciona esta espécie no grupo longistyla juntamente com $N$. kiautai, $N$. longistyla and $N$. nitens, mas difere delas principalmente pelo formato do cerco, com a parte carenada ocupando 0,33 do comprimento total e também pelos tubérculos dorsal, ventro-mediano e ventro-lateral desenvolvidos. Um processo incomum na porção tergal do protórax é mencionado pela primeira vez em Navicordulia. Além disso, a taxa de descrição de novas espécies Sul-Americanas de 'Corduliidae' é discutida. Um mapa com os registros das espécies de Navicordulia da Mata Atlântica e uma lista por estado dos corduliídeos brasileiros são também apresentados.

PALAVRAS-CHAVE. Anisoptera; Corduliinae; libélula; morfologia; taxonomia.

Navicordulia Machado \& Costa, 1995 is the second most rich 'Corduliidae' genus occurring in the Neotropical region with ten species: N. amazonica Machado \& Costa, 1995; N. atlantica Machado \& Costa, 1995; N. errans (Calvert, 1909); N. kiautai Machado \& Costa, 1995; N. leptostyla Machado \& Costa, 1995; N. longistyla Machado \& Costa, 1995; N. mielkei Machado \& Costa, 1995; N. miersi Machado \& Costa, 1995; N. nitens (De Marmels, 1991); and N. vagans (De Marmels, 1989). Machado \& Costa (1995) established Navicordulia to include three outstanding South American species ascribed to Dorocordulia Needham, 1901 (D. errans, D. nitens and D. vagans), thus solving the biogeographical problem raised by Calvert (1909) with the presence of a strictly Nearctic genus in South America. These authors also described seven new species in that paper, all from Brazil.

These metallic greenish dragonflies are distributed in the three major South American biomes: Amazonian Forest (in Brazil and Venezuela), Brazilian Cerrado, and Atlantic Forest, all within the interior of forested and open areas (Santos 1968a; De Marmels 1989, 1991; Machado \& Costa 1995). The genus can be diagnosed by the following characters: males with the posterior inner margin of hind wing with a accentuated excavation distal to anal triangle, and with a pilose complex on sternite of S7 composed of hair-like setae on a mediolongitudinal and one or two transverse carinae plus a pair of hair-like setal patches on posterior portion of ventral carina of tergite S7; female subgenital plate boat shaped, posteriorly projected beyond S10, and with a supralaminar process (sternite S9) also projected posteriorly into spoon, dish or tongue-shaped structure (Machado \& Costa 1995; Garrison et al. 2006). The only ultimate larval stadium described is that of $N$. nitens, based on the exuvia of the holotype (De Marmels 1991). As with other Neotropical 'Corduliidae', there is little information on the biology and distribution of Navicordulia; Machado \& Costa (1995) provided the most extensive account on spatial and altitudinal distribution, and general ecology.

The phylogenetic relationships among representatives of the paraphyletic or polyphyletic taxon 'Corduliidae' are far from being agreed upon. Although definitions of monophyletic groups still await further study, some recent efforts at elucidating the hierarchical relationships of 'Corduliidae' both at higher and lower taxonomic levels (e.g. Fleck \& Legrand 2006; Ware et al. 2007, 2009; Bybee et al. 2008; Pinto \& Carvalho 2010) have been presented, but no species of Navicordulia was included. 
Recently, Heckman (2006) provided a modified version of the identification key to species presented by Machado \& Costa (1995) and as noted for other genera in that work (cf. von Ellenrieder \& Garrison 2008; Carvalho et al. 2009), his key contains errors or incomplete data such as the geographic distributions of $N$. mielkei and $N$. nitens. Garrison et al. (2006) included Navicordulia in an identification key for the New World genera of Anisoptera, diagnosing it and showing a thumbnail map with its known distribution.

We describe and illustrate a new species from Santa Catarina State, Southern Brazil, update the key by Machado $\&$ Costa (1995) in order to include the new species, and a map the Atlantic Forest species is also presented.

\section{MATERIAL AND METHODS}

Specimens examined are deposited in the following Brazilian institutions with their respective acronyms and curators: Coleção Entomológica Prof. José Alfredo Pinheiro Dutra, Departamento de Zoologia, Instituto de Biologia, Universidade Federal do Rio do Janeiro (DZRJ, Jorge L. Nessimian and Nelson Ferreira-Jr); Departamento de Entomologia, Museu Nacional, Universidade Federal do Rio do Janeiro (MNRJ, Janira Martins Costa); and Serviço de Invertebrados, Museu de Zoologia, Universidade de São Paulo (MZSP, Sônia Casari).

Nomenclature of general morphology was based on Asahina (1954) and Garrison et al. (2006), except for the specific structures of Navicordulia where we adopt the names introduced by Machado \& Costa (1995); the wing venation terminology follows Riek \& Kukalová-Peck (1984) with additions summarized by Fleck et al. (2003). Nomenclature proposed by Pfau (2005) was implemented for description of the structures of the vesica spermalis (VS). VS was extracted together with the sternite of S3 after relaxing the specimen with drops of $10 \%$ ammonia solution on the venter of S2-3. The VS was immersed in $10 \% \mathrm{KOH}$ solution for few hours under room temperature and subsequently rinsed in water. Material was later stored in a microvial with glycerin and maintained together with their respective specimen. Measurements (in $\mathrm{mm}$ ) and illustrations were made with the aid of a stereomicroscope equipped with a camera lucida. Specimens were photographed with a Leica MZ16 stereomicroscope equipped with a Leica DFC420 camera, and source images combined using Auto-montage software by The Synoptic Group $\subset$. The following abbreviations were used along the text: $\mathrm{Ax}=$ antenodal crossveins; $\mathrm{Fw}=$ fore wing; $\mathrm{Hw}=$ hind wing; $\mathrm{LC}=$ lateral abdominal carina; $\mathrm{Px}=$ postnodal crossveins; $\mathrm{pt}=$ pterostigma; $\mathrm{S} 1-10=$ abdominal segments; $\mathrm{TC}=$ abdominal transverse carina; $\mathrm{VS}=$ vesica spermalis; V1-V4 = vesica spermalis segments.

Geographic records represented in the map are based on literature and voucher material, and was generated using ArcView 3.2 (ESRI 1999). Geographic coordinates not provided in the collection labels or original papers were acquired from a digital database (IBGE 2007).

\section{Navicordulia aemulatrix sp. nov.}

(Figs. 1-2, 4-5, 7-13)

Holotype male. BRAZIL. Santa Catarina State, [São Bento do Sul municipality, $\left.26^{\circ} 14^{\prime} 58^{\prime \prime} \mathrm{S}, 4^{\circ} 22^{\prime} 59^{\prime \prime} \mathrm{W}\right]$, [railway station] Rio Vermelho, II.1952, [Richard von] Dirings[hofen] leg. (MZSP). Paratypes. 2 males, same data as the holotype, except II.1952 (MZSP) and I.1953 (MNRJ).

Diagnosis. Medium-sized corduliid, predominately brown with metallic green reflections (Fig. 1), accentuated excavation posterior to anal triangle of $\mathrm{Hw}$, posterior hamule unbranched, directed posteriorly with a recurved apex, and with pilose complex on sternite of S7 (Figs. 4-5), typical of genus. The long cercus, distinctly longer than epiproct places this species in the longistyla-group, together with $N$. kiautai, $N$. longistyla, and $N$. nitens. The following unique combination of characters will separate it from all other species: postfrons with metallic blue reflections, differing from the largely metallic green thorax (Fig. 1); maximum width of abdomen (S7-8) from 2.85-2.9; a single transversal carina at the pilose complex on sternite of S7 (Fig. 5); dorsal, ventro-lateral and ventro medial tubercles of cercus developed; cercus length 2.9-3.2, the largest within the genus; ratio between epiproct length and that of cercus $0.58-0.62$; carinated part of cercus distinctly shorter than non-carinated (ratio of carinated part / total length of cercus $\leq 0.33$ ) (Figs. 7-9).

Description of male holotype. Head (Fig. 1). Face in anterior view four banded, interlaced with dark and pale transversal stripes; covered with dark brown setae, except for yellow setae on labium and free margins of postclypeus. Labium light orange; median lobe with an ill-defined longitudinal dark line centrally, posterior margin with very narrow dark line extended laterally to 0.4 of palpiger's length. Labrum orange; clypeolabral suture with three small dark spots, a central and a pair on each side. Clypeus brownishorange; central portion of postclypeus irregularly spotted with orange. Frons with a deep furrow; ventral half of antefrons orange without metallic reflections, darkening to brown dorsally with metallic blue reflections; postfrons brownish with metallic blue reflections above, lateral parts brownishorange. Vertex brown, with metallic blue reflections; anterodorsal area between the barely developed tubercles with a suboval orange spot. Antenna with flagellum broken; scapus brown, pedicel dark brown to black. Occipital triangle brown; rear of head orange with irregular dark areas.

Thorax (Figs. 1-2). Pronotum with anterior margin of anterior lobe pale yellow; dorsal part of anterior lobe and antero-lateral margin of middle lobe brownish-orange; dorsolateral portion of middle lobe orange; central portion of middle lobe and posterior lobe brown; suture between middle and posterior lobes with a small cylindrical yellowish process directed dorsally (Fig. 2). Propleura anteriorly yellowish, posteriorly brownish. Synthorax brown with metallic green reflections; ventral surface, antealar sinus, interalar sclerite 


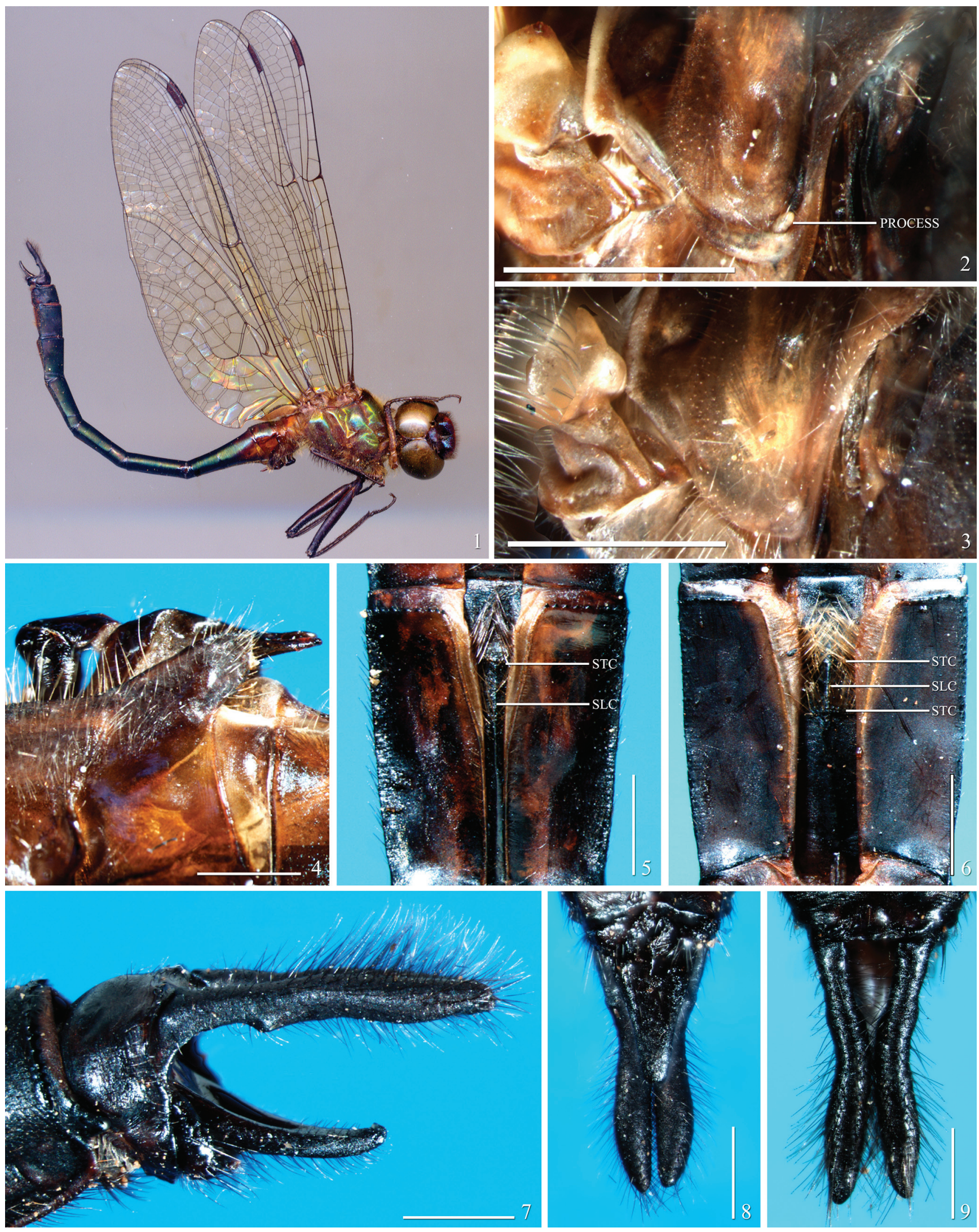

Figs. 1-9. 1-2, 4, 7-8, Navicordulia aemulatrix sp. nov. holotype male; 5 and 9, same but paratype male in MZSP; 3, Neocordulia setifera male (Brazil. RJ: Teresópolis); 6, Navicordulia errans male (Brazil. GO: Jataí); 1, scanned image of holotype specimen; 2-3, detail of prothorax in lateral view; 4, S2-3 in lateral view; 5-6, S7 in ventral view; 7-9, caudal appendages in lateral (7), ventral (8) and dorsal views (9); SLC = sternite longitudinal carina, STC = sternite transversal carina. Scale bars $=1 \mathrm{~mm}$. 

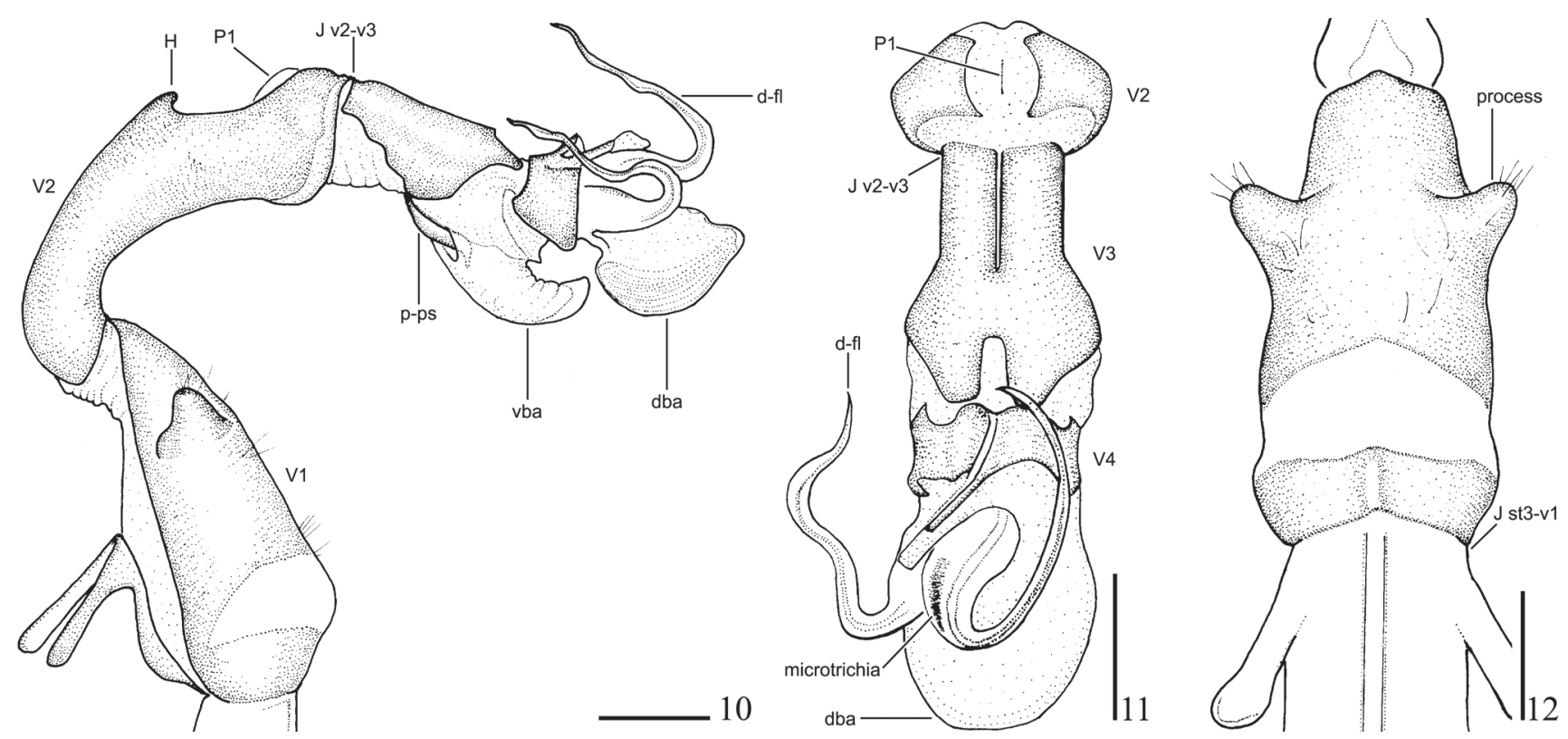

Fig. 10-12. Vesica spermalis of Navicordulia aemulatrix sp. nov. (MNRJ paratype male); 10, lateral view of V1-V4; 11, dorsal view of V2-V4; 12, ventral view of V1; dba, distal balloon; d-fl, distal flagellum; H, dorso-apical hump of V2; J st3-v1, joint of sternum of S3 and V1; Jv2-v3 and Jv3-v4, joints between segments of vesica spermalis; P1, filling-pore of the sperm-reservoir; p-ps, proximal pump-sclerite; V1-V4, segments of vesica spermalis; vba, ventral balloon. Scale bars $=1 \mathrm{~mm}$.

and metapostepimeron brown without metallic reflections; entire surface covered with yellowish hair-like setae, except antealar sinus with short brown setae. Legs dark brown to black; coxa, postero-ventral surface of prothoracic trochanter and femur, and dorsal surface of metathoracic leg lighter; tarsal claws brown. Tibial keels pale brown, occupying 0.26 of pro, 0.15 of meso and 0.79 of metathoracic tibiae; apex of keels acutely projected.

Wings. Membrane thinly tinged of smoky yellow, darker at extreme distal and wing margins; venation dark-brown to black, costal triangle pale-brown; pt brown, paler than adjacent veins, slightly trapezoidal, distal side most oblique; membranula with extreme antero-distal base and after fusion of anal veins whitish, remainder brown to dark-brown. Venation as follows: 8-10 Ax in Fw, $5 \mathrm{Ax}$ in Hw; 4-5 Px in Fw, 6-7 Px in Hw; 3 postsubnodals in Fw, 4 in Hw; bridge crossvein arising on RP2, beyond subnodus and closer to oblique vein; arc between Ax1-2, but closer to Ax2, close to Ax2 $0.28-0.30$ of the distance between Ax1-2 in Fw and 0.4 in Hw; sectors of arc not stalked, origin located on basal 0.30 of arc in Fw, 0.28 in Hw; RP3-4 not undulate in four wings; Rspl distinct, with one cell row, composed by 5 cells in Fw, 6 in $\mathrm{Hw}$; discoidal triangles, supratriangles and subtriangles not crossed in four wings; subtriangles with a vestige of crossvein in both Fw; hind wing triangle base arising distinctly proximal to arc; space between CuP-crossing and proximal side of discoidal triangle, not crossed in all wings; Fw discoidal field slightly convergent, with two rows of cells over its entire length, increasing to three cells at wing margin; Fw MA meets the wing margin at level of second cell of Rspl, Fw MP meets the wing margin at origin of Rspl; Hw discoidal field divergent, with 3-5 rows of 2 cells, 1-2 of 3 cells, 1-2 of 4 cells and 7-8 cells in the wing margin; Hw MA meets the wing margin between first and second cells of Rspl, Hw MP meets the wing margins near to level of costal nodus; Mspl indistinct in Fw (weakly defined with 4 cells) and Hw (weakly defined with 5 cells); anal loop elongated with distinct midrib, reaching distally near the RP-midfork level; total of cells in anal loop 12-13 (proximal row 6 cells, distal 6-7); apex of anal loop slightly dilated; anal triangle with two cells, crossed 0.34 posterior, anterior side 0.34 of the distal side length; space between AA1b and AA2b with one cell at base; space between anal loop and posterior border of wing with 2 cell rows; Fw PsA ends near the proximal angle of triangle or distinctly posterior MP fork.

Abdomen (Figs. 1, 4). Cylindrical, posterior segments expanded; S1 to anterior 0.33 of S3 slightly swollen dorsally; posterior 0.66 of S3 to S5 cylindrical; S6 up to joint of S7-8 swelling, after narrowing to S10; S1-4 and S9 without LC, barely distinct after TC in S5 and distinct in S6-S8; dorsal keel poor defined on anterior half of S10. Ground color brown to black; S1 and S2 anterior to TC and its ventral half, brownish; dorsal half of S2 to S3-9 with metallic green reflections, posterior half of S7 to S8-9 with cupreous reflections; ventral carina of S3-8 yellowish, in S9 brown; ventro-tergal areas of S3-5 with metallic green reflection like as the dorsal part, in S6-9 dark brown, paler distally in S7-8; sternites dark brown to black. Pilose complex on the sternite of S7 not completely visible, but indicating a single transversal carina; pilose complex on $\mathrm{S} 8$ covered by brownish setae on 0.66 anterior, after yellowish. Auricles rounded, in lateral view 0.35 of S2 height; internal surface smooth, without denticles. Cerci (Figs. 7-8) dark brown; cylindrical; in lateral view 0.14 proportionally longer than $\mathrm{S} 9+10$; covered with 
hair-like posteriorly directed setae, more dense on posterior 0.66 of cercus length; in dorsal view anterior half convergent, then almost parallel; posterior half intumesced with internal margin almost straight and external margin convex, apex rounded (blunt) and slightly convergent. Dorsal surface with a small tubercle at base; ventral surface with a ventro-lateral and a ventro-medial carinae, the latter less distinct; ratio of carinated part / total length of cercus 0.33 ; a strong ventrolateral tubercle, partially visible in dorsal view, and a less pronounced ventro-medial tubercle at end of each carina. Epiproct (Figs. 7-8) dark brown; triangular; apex acute curved upwards, the spines fused into only one process; extending 0.62 of cercus length in lateral view.

Genital fossa (Fig. 4). Anterior lamina pale brown, posterior margin strongly concave with a horseshoe-like ridge in shape; lateral portions posteriorly projected. Posterior hamule (Fig. 4) brown, typical of the genus, unbranched, sickle shaped and higher than genital lobe; the slender externally recurved part extended posteriorly slightly beyond end of first segment of VS; apexes divergent, with a minute black spine directed outward. Genital lobe (Fig. 4) brown, well developed and robust, subquandrangular; directed oblique and posteriorly reaching 0.66 of the length of posterior field of S2 in lateral view; external surface covered with scattered setae. Vesica spermalis (based on one paratype when inflated, Figs. 1012). Ventral surface of V1 with a pair of strong obliquely projected processes in distal 0.33 , its apex covered with hair-like setae; V2 almost tubular in shape, distally enlarged at level of the filling-pore of the sperm-reservoir (P1) up to articulation between V2-V3 ( $\mathrm{J}$ v2-v3); ventral surface of V3 membranous with a distinct proximal pump-sclerite (p-ps); ventral balloon (vba) greatly developed and projected ventroanteriorly; dorso-distal portion of $\mathrm{V} 3$ before the joint between V3 and V4 (J v3-v4) with the pair of proximal horns (ph) barely projected; V4 somewhat asymmetrical, with unequal projection rising from the sclerotized plate and undefined distal horns (dh); the pair of long distal flagella (d-fl) also not completely symmetrical both in length and shape; left flagellum covered with a field of microtrichia on the base; distal balloon (dba) rounded with the surface on ventral half densely covered with very small spine-like processes.

Measurements. Total length (incl. caudal appendages) 46; abdomen length (excluding caudal appendages) 31; maximum width of head 7; eyes seam length 1; length of $\mathrm{Fw}$ 30 , Hw 29; width of wing (proximal to costal nodus) 7 in Fw, 8.9 in Hw; length of distance of base-nodus 17 in Fw, 13.25 in HW; ratio between base-nodus distance / total length of wing 0.57 in Fw, 0.46 in Hw; pt length 2.3 in Fw, 2.2 in Hw; length of postnodal space (sensu May 1991) 0.59 in Fw, 0.49 in $\mathrm{Hw}$; length of metathoracic femur 6.8; metathoracic tibia 6.3; length of genital lobe 1.3; width of base of genital lobe 1.1; length of hamule in lateral view (anterior to posterior margins) 2.2; maximum width of abdomen (between S7-8) 2.85 ; length of S9+10 in lateral view 2.5 ; total length of cercus in lateral view 2.9; length of uncarinated part of cercus in lateral view 1.95; length of epiproct in lateral view 1.8.

Variations in male paratypes. The two male paratypes are

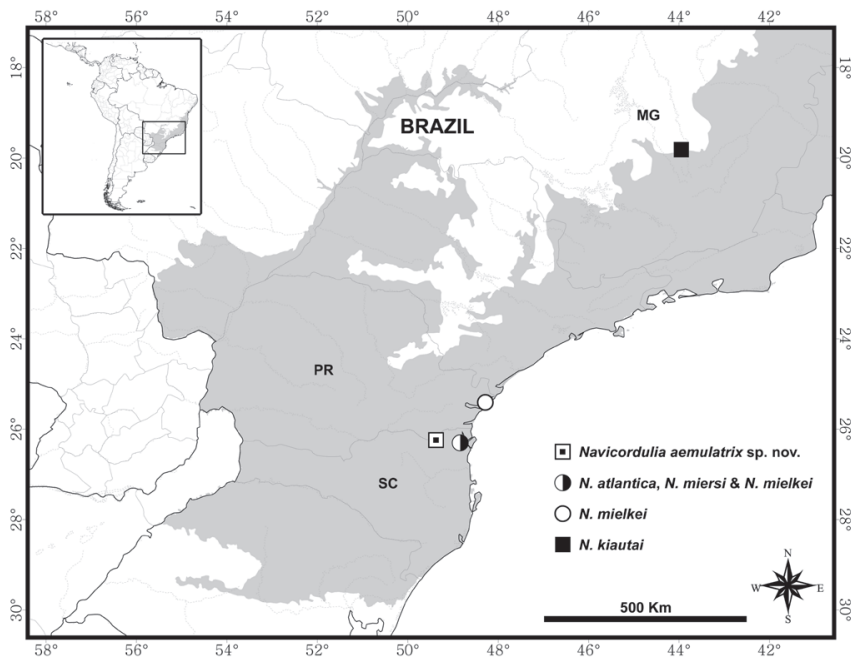

Fig. 13. Map of Southeastern Brazil with the distribution records of Atlantic Forest species of the genus Navicordulia. Shaded area corresponds to original extension of Atlantic Forest in Brazil. Abbreviations for Brazilian States: MG, Minas Gerais; PR, Paraná; SC, Santa Catarina.

very similar to holotype except as follows: median lobe of labium lacking ill-defined longitudinal dark line centrally; in one paratype, the central dark spot on the clypeolabral suture is absent; metallic reflections on postfrons with blue color less intense; antenna with flagellum dark brown; occipital triangle brown with a pair of lateral orange longitudinal stripes connected with orange of the rear of head; LC barely distinct before and distinct after TC in S4-S5; pilose complex on the sternite of S7 visible and with a single transversal ridge (Fig. 5); ratio between cerci and S9+10 in lateral view 0.150.16 ; epiproct extending $0.58-0.59$ of cercus length in lateral view; 5-6 Ax in Hw; 5-6 Px in Fw, 7-8 in Hw; arc close to Ax2 between $0.20-0.39$ of the distance between Ax1-2 in Fw and 0.34-0.40 in Hw; two bridge crossveins in $\mathrm{Fw}$ and $\mathrm{Hw}$, the proximal rising close to or at subnodus, the distal close or very close to oblique vein; Rspl composed by 5-7 cells in Fw; subtriangles crossed, with two cells; one paratype has the Fw discoidal field with two rows of cells up to RP-midfork, then one row of three cells, after rows of two cells increasing to three cells at margin; Fw MA meets the wing margin at level of second cell of Rspl, Fw MP meets the wing margin at origin of Rspl; Hw discoidal field divergent, with 3-4 rows of 2 cells, 4 of 3 cells, $1-2$ of 4 cells and 9-11 cells at the wing margin; Hw MA meets the wing margin at origin of Rspl; Mspl indistinct in Fw (weakly defined with 4-5 cells), in Hw weakly defined with 4-5 cells, the distal ends not clear; total of cells in anal loop 14-16 (proximal row 7-8 cells, distal 7-8); apex of anal loop truncate to slightly dilated; anal triangle crossed in 0.36 0.44 posterior, anterior side $0.35-0.36$ of distal side length; Fw PsA ends near the proximal angle of triangle or before MP fork. Measurements. Total length 47.5-48.5; abdomen length 30.8-33.3; maximum width of head 6.9-7.5; length of Fw 30-31, Hw 29-30; width of wing 7.2-7.8 in Fw, 9.5-10.5 in Hw; length of distance of base-nodus 16.5-18.3 in Fw, 1314 in HW; ratio between base-nodus distance / total length 
of wing 0.58-0.60 in Fw, 0.44-0.46 in Hw; pt length 2.3-2.4 in $\mathrm{Fw}, 2.1-2.3$ in $\mathrm{Hw}$; length of postnodal space $0.51-0.52$ in Fw, 0.46-0.47 in Hw; length of metathoracic femur 7.0-7.1; metathoracic tibia 6.8 ; length of genital lobe 1.3 ; tibial keels occupying $0.25-0.30$ of pro-, $0.15-0.19$ of meso- and $0.76-$ 0.79 of metathoracic tibiae length; length of hamule in lateral view 2; maximum width of abdomen 2.85-2.9; length of $\mathrm{S} 9+10$ in lateral view 2.5-2.7; total length of cercus in lateral view 2.9-3.2; length of uncarinated part of cercus in lateral view 1.95-2.15; length of epiproct in lateral view 1.7-1.9.

Female and larva unknown.

Etymology. The Latin word aemulatrix (f., emulate; to try to equal or surpass) is a reference to intermediate features observed in the new species 'imitating' those of N. kiautai and $N$. longistyla.

Remarks. The holotype is in a very good state of preservation, except the small area with a drop of glue uniting S4-5. In one paratype, the abdomen is broken between S4-5. The head and a prothoracic leg are detached with all parts in a small cellophane envelope and the sternum of S3 removed with VS. Another paratype is a perfectly pinned specimen set laterally with the pin passing close to metathoracic spiracle. To guarantee its preservation the pin was removed and the specimen was transferred to a cellophane envelope.

\section{DISCUSSION}

Based on the size of male caudal appendages, Machado \& Costa (1995) divided Navicordulia in two groups: longistylagroup (cercus length 2.5-2.9 mm) including $N$. kiautai, $N$. longistyla and $N$. nitens, and errans-group (cercus length 1.6$2.0 \mathrm{~mm}$ ) including $N$. atlantica, $N$. errans, $N$. leptostyla, $N$. mielkei and $N$. vagans. Two species ( $N$. amazonica and $N$. miersi) are known only from female holotypes and cannot be placed in either group with certainty. The unrestricted adoption of this character as the unique criterion for the establishment of groups in the genus can be judged somewhat arbitrary since choosing of any other character, e.g. the vesica spermalis or even the pilose complex on $\mathrm{S} 7$, if independently used, will suggest different grouping of species. However, until more comprehensive studies are developed, and in order to facilitate the comparison, we followed Machado \& Costa (1995) in adopting this division.

Within the longistyla-group, the new species can be easily distinguished from the Venezuelan $N$. nitens by its reduced carinated portion occupying 0.33 of cercus length in $N$. aemulatrix sp. nov. (Fig. 7) while in N. nitens it occupies ca. 0.66 . The new species will key out between N. kiautai and N. longistyla in Machado \& Costa (1995: 197) and a modification of couplet 3 will allow its identification:

3. Dorso-basal tubercle poorly developed and the ventrolateral tubercle vestigial to absent; ventro-medial tubercle visible in dorsal view; maximum width of abdomen between S7-8 from 2.3-2.4; Cerrado species, Distrito Federal in Brazil ......................... N. longistyla Dorso-basal and ventro-lateral tubercles developed, the latter partially visible in dorsal view; ventro-medial tubercle poorly developed, not visible in dorsal view; maximum width of abdomen between S7-8 from 2.8-

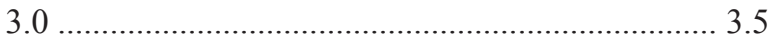

3.5.Caudal appendages with carinated part as long as the non-carinated (ratio of carinated part / total length of cercus ca 0.48); cercus slightly longer than epiproct (ratio between epiproct / total length of cercus $\geq 0.77$ ); postfrons with metallic green reflections, similar to thoracic coloration; Cerrado / Atlantic Forest species, Minas Gerais State in Brazil (Fig. 13) .......... N. kiautai

Caudal appendages with carinated part distinctly shorter than non-carinated (ratio of carinated part / total length of cercus $\leq 0.33$ ); cercus distinctly longer than epiproct (maximum ratio between epiproct / total length of cercus ca 0.62) (Figs. 7-9); postfrons with metallic blue reflections, differing from largely metallic green thorax (Fig. 1); Atlantic Forest species, Santa Catarina State in Brazil (Fig. 13) ........................ N. aemulatrix sp. nov.

A conspicuous cylindrical yellowish process on the tergal portion of prothorax, placed on the suture between middle and posterior lobes, was observed in the specimens of $N$. aemulatrix sp. nov. (Fig. 2). In order to check this character in other Neotropical corduliids, specimens of Navicordulia errans (2 males, Goiás State, Brazil), Neocordulia setifera (Hagen in Selys, 1871) (2 males, Rio de Janeiro State, Brazil), Lauromacromia luismoojeni (Santos, 1967) (1 male, Mato Grosso do Sul State, Brazil), L. melanica Pinto \& Carvalho, 2010 (males holotype and paratype, Espírito Santo State, Brazil), and L. picinguaba Carvalho, Salgado \& Werneck-deCarvalho, 2004 (1 female paratype, São Paulo State, Brazil) were also examined. This structure is absent, or extremely reduced, in N. setifera (Fig. 3) and in N. errans, but certainly absent in L. luismoojeni, L. melanica and L. picinguaba. The character also shows some conspecific variation, as the paratypes of $N$. aemulatrix sp. nov. show the process less developed than the holotype. The tubercle seems also to be absent in Navicordulia leptostyla and N. longistyla, as well as, on examined species of another genera such as Aeschnosoma forcipula Hagen in Selys, 1871, Neocordulia campana May \& Knopf, 1988, N. caudacuta De Marmels, 2008, N. griphus May, 1991 and Schizocordulia rustica (Hagen in Selys, 1871) (R. Garrison, pers. comm.). This character may be useful in future taxonomic and phylogenetic analyses on 'Corduliidae'.

Machado \& Costa (1995) stated that the anterior lamina in males of Navicordulia is absent in the Brazilian species and controversially present in the Venezuelan ones. In this latter case, the authors cited a letter from J. De Marmels (p. 195). If true, the absence of anterior lamina in males of Brazilian Navicordulia may represent a unique condition among all species of Odonata. However, this structure is present in $N$. aemulatrix sp. nov., $N$. errans (see Garrison et al. 2006: Fig. 886a), and $N$. longistyla. The possible discordance in the interpretation of morphology of the anterior lamina in 
Table I. Published records of 'Corduliidae' species occurring in Brazil by State. States with records not under species level or even absent were omitted. Abbreviations for Brazilian States: AM, Amazonas; BA, Bahia; DF, Distrito Federal; ES, Espírito Santo; GO, Goiás; MT, Mato Grosso; MS, Mato Grosso do Sul; MG, Minas Gerais; PA, Pará; PR, Paraná; RJ, Rio de Janeiro; RS, Rio Grande do Sul; SC, Santa Catarina; SP, São Paulo.

\begin{tabular}{|c|c|c|c|c|c|c|c|c|c|}
\hline Species / States & AM & BA & DF & ES & $\mathrm{GO}$ & MT & MS & MG & $\mathrm{P}$ \\
\hline Aeschnosoma auripennis Geijskes, 1970 & 15 & & & & & & & & \\
\hline A. elegans Selys, 1870 & & & & & & & & & 18 , \\
\hline A. forcipula Hagen in Selys, 1871 & $\begin{array}{l}18,19 \\
26,36\end{array}$ & & & 8,36 & & & & & $\begin{array}{r}14, \\
1\end{array}$ \\
\hline A. marizae Santos, 1981 & & 16 & $\begin{array}{c}7,10 \\
19,36\end{array}$ & & & & & & \\
\hline
\end{tabular}

machadoi (Costa \& T. C.

Santos, 2000)

C. marshalli (Costa \& T. C.Santos, 1992)

C. newtoni (Costa \& T. C. Santos, 2000)

Lauromacromia bedei Machado, 2005

L. dubitalis (Fraser, 1939)

23

L. flaviae Machado, 2002

L. luismoojeni (Santos, 1967)

L. melanica Pinto \& Carvalho, 2010

L. picinguaba Carvalho, Salgado \&

Werneck-de-Carvalho, 2004

Navicordulia aemulatrix sp. nov. Pinto \&

Lamas

Na. amazonica Machado \& Costa, 1995

Na. atlantica Machado \& Costa, 1995

Na. errans (Calvert, 1909)

Na. kiautai Machado \& Costa, 1995

Na. leptostyla Machado \& Costa, 1995

Na. longistyla Machado \& Costa, 1995

Na. mielkei Machado \& Costa, 1995

Na. miersi Machado \& Costa, 1995

Neocordulia androgynis (Selys, 1871)

Ne. batesi batesi (Selys, 1871)

Ne. carlochagasi Santos, 1967

27

Ne. fiorentini Costa \& Machado, 2007

Ne. gaucha Costa \& Machado, 2007

Ne. mambucabensis Costa \& T.C.Santos, 2000

Ne. matutuensis Machado, 2005

Ne. santacatarinensis Costa, Ravenello \&

Souza-Franco, 2008

Ne. setifera (Hagen in Selys, 1871)

28

8,19

14,18 ,

19

$\begin{array}{ccc} & & 10,12, \\ & & 7,9, \\ & & 19\end{array}$

19,21

$7,19, \quad 28$

31

28,29

$4,5,19$,

28,29

29

19,25

19,25

\begin{tabular}{|c|c|}
\hline $\begin{array}{c}17,19, \\
25\end{array}$ & $\begin{array}{c}19,25, \\
29\end{array}$ \\
\hline $\begin{array}{c}7,19, \\
25\end{array}$ & $\begin{array}{c}7,19, \\
25\end{array}$ \\
\hline $\begin{array}{c}7,17 \\
19,25\end{array}$ & \\
\hline
\end{tabular}

12,19 , 25,33

19,25

$25 \quad 19,25$

19,25

10,11,
19,26,

19,26 ,

27,34

2,7

11,19 ,

27,32

$11,19,1,11$,

$26,2719,20$,

27

11,19 ,

26, 27,

30

17,18 ,

19,26
14,18 ,

19,22 ,

chizocordulia rustica (Hagen in Selys,

26

$\begin{array}{lllllllllllllll}26 & & & \\ \text { Total of species: } 34 & 4 & 2 * & 5 & 2 & 3 & 5 & 1 & 8 & 4 & 4 & 6 & 3 & 6 & 7\end{array}$

1. Calvert (1909); 2. Carvalho \& Kloosterman (2001); 3. Carvalho \& Nessimian (1998); 4. Carvalho et al. (2004); 5. Carvalho et al. (2008); 6. Costa \& Machado (2007); 7. Costa \& Mascarenhas (1998); 8. Costa \& Oldrini (2005); 9. Costa \& Santos (1992); 10. Costa \& Santos (2000a); 11. Costa \& Santos (2000b); 12.

Costa et al. (2000); 13. Costa et al. (2008); 14. Cowley (1934); 15. De Marco (1998); 16. Fleck et al. (2009); 17. Garrison et al. (2006); 18. Geijskes (1970); 19. Heckman (2006); 20. Longfield (1929); 21. Machado (2002); 22. Machado (2005a); 23. Machado (2005b); 24. Machado (2005c); 25. Machado \& Costa (1995);

26. Martin (1906); 27. May (1991); 28. Pinto \& Carvalho (2010); 29. Present work; 30. Santos (1966); 31. Santos (1967a); 32. Santos (1967b); 33. Santos (1968a);

34. Santos (1968b); 35. Santos (1970); 36. Santos (1981); 37. Vick \& Chelmick (2001). *Fleck et al. (2009) cited two new species of Aeschnosoma from Bahia, however its inclusion pending a formal description. 
Navicordulia may be due the weak level of sclerotization of this sclerite.

The current rate of the species descriptions of South American corduliids is impressive; half of the 43 species was described in the last twenty years and almost one-third within the current decade (based on data from Garrison 2009). All recently described species are from the Neotropical portion of the continent (sensu Morrone 2006), while the corduliids from Andean region / South American transition zone seem near to be completely discovered, although there is at least one undescribed species of Gomphomacromia from Colombia (R. Garrison pers. comm.). One would relate the data to the recent increase in field surveys, but after checking the collecting dates in respective type series we were able to realize that just the smaller part (40\%) of the descriptions was based on specimens collected in the last two decades. This scenery is accentuated in Navicordulia, since from the total of eight species described in the last twenty years; seven of them were based on specimens collected at maximum in the decade of 1980. It can demonstrate a trend of reduction of collection expeditions and it becomes critical to increment actions for promote future field surveys. The Neotropical region is largely considered to be the richest dragonfly biota of the World and also the least studied (Kalkman et al. 2008; von Ellenrieder 2009). Corduliids are poorly represented in this region, however they have been shown to be richer than previously expected and probably several new taxa will be discovered. Furthermore, there is a gap in biological and ecological knowledge of South American 'Corduliidae' facing the current biodiversity crisis (see Clausnitzer et al. 2009), field surveys must be the priority effort for assessment of the diverse dragonfly fauna of tropical South America (von Ellenrieder 2009; Pinto \& Carvalho 2010).

The discovery of N. aemulatrix sp. nov. in Santa Catarina, brings the total number of 'Corduliidae' species recorded for that State to six; the same as recorded for Rio de Janeiro, and less than recorded for São Paulo and Minas Gerais states, with seven and eight species respectively (Table I). The last two States have different types of vegetation, Atlantic Forest and Cerrado, which could explain their diversity, but the relative higher richness in these three southeastern Brazilian States can be more directly related to the concentration of active specialists in this region (De Marco \& Vianna 2005). Remarkably, the northeastern Santa Catarina has the higher number of species of Navicordulia with four species recorded (Table I). Furthermore, the resemblance between N. kiautai and the $N$. aemulatrix sp. nov. indicates that the first species is an Atlantic Forest species (Fig. 13) as previously suggested by Machado \& Costa (1995: 202).

This contribution is the first report on our studies based on Richard von Diringshofen's dragonfly collection incorporated in 1987 to the entomological collection of Museu de Zoologia da Universidade de São Paulo (MZSP) (cf. Costa et al. 2000).

\section{Additional material examined}

Lauromacromia luismoojeni. 1 male. BRAZIL. Mato Grosso do Sul State:
Três Lagoas (boundary with Castilho municipality in São Paulo State), X.1964[?], (MZSP).

Lauromacromia melanica. 2 males. [BRAZIL]. E[spírito] Santo [State], Conceição da Barra, Sítio de José Campista (forest), 1-6.XII.1969, Elias leg. 1 male holotype and 1 male paratype (MNRJ).

Lauromacromia picinguaba. 1 female. BRAZIL. São Paulo State: Parque Estadual da Serra do Mar, Núcleo Picinguaba, 24.XI.2001 [adult's emergence data], female paratype (DZRJ).

Navicordulia errans. 2 males. BRAZIL. Goiás State: Jataí, Fazenda Nova Ordlândia, I.1964, Martins, Morgante \& Silva leg. (MZSP).

Navicordulia longistyla. 2 males. BRAZIL. Distrito Federal State: Brasília, Reserva Biológica do IBGE, road in Cerrado, [collected] 6:30 a.m., 28.X.1980, Santos, N.D. \& Mesquita, H. leg., male holotype (MNRJ $\mathrm{n}^{\circ}$ 442); same data as holotype but Chácara São Vicente, near a gallery forest, [collected] 6:00 a.m., 28.X.1979, [Keiko leg.?], 1 male paratype (MNRJ).

Neocordulia setifera. 2 males. BRAZIL. Rio de Janeiro State: Itatiaia, Parque Nacional do Itatiaia (IT 52), 12.IV.2007, Ferreira-Jr., N. leg., 1 male (DZRJ); Serra do Subaio, Teresópolis, 30-31.III.1996, Carvalho. A.L. \& Equipe do Laboratório de Entomologia leg., 1 male (DZRJ).

Acknowledgements. We are indebted to all curators of those collections examined and we especially thank: Dr. Alcimar Carvalho (MNRJ, Brazil) for allowing use of his laboratory and also for access to his personal odonatological library; Dr. Janira Martins Costa (MNRJ, Brazil) for kindly allowing the study of all type material of Navicordulia deposited in MNRJ; Dr. Rosser W. Garrison (CDFA, U.S.A) for checking characters in specimens deposited in your personal collection (registered with USNM); Dr. Angelo B. M. Machado (UFMG, Brazil) for sending his reprints on Corduliidae; Dr. Alcimar Carvalho and Jerrell J. Daigle (Tallahassee, Florida, USA) for reviewing the manuscript. Thanks are due Dr. Rosser W. Garrison (CDFA, U.S.A) and another anonymous reviewer for the useful suggestions in the final version of the manuscript. This study was partially supported by Brazilian government agencies, Coordenação de Aperfeiçoamento de Pessoal de Nível Superior (CAPES, Ph.D. fellowship to the first author) and Fundação Carlos Chagas Filho de Amparo à Pesquisa do Estado do Rio de Janeiro (FAPERJ processes numbers E-26/170.644/2004 and E-26/171.281/2006).

\section{REFERENCES}

Asahina, S. 1954. A morphological study of a relic dragonfly Epiophlebia superstes Selys (Odonata, Anisozygoptera). Tokyo, The Japan Society for Promotion of Science, 1xxi+153 p.

Bybee, S. M.; T. H. Ogden; M. A. Branham \& M. F. Whiting. 2008. Molecules, morphology and fossils: a comprehensive approach to odonate phylogeny and the evolution of the odonate wing. Cladistics 23: $1-38$.

Calvert, P. P. 1909. Contributions to a knowledge of the Odonata of the Neotropical Region exclusive of Mexico and Central America. Annals of the Carnegie Museum 6: 73-280.

Carvalho, A. L. \& R. R. Kloosterman. 2001. Descrição da larva de Neocordulia carlochagasi Santos, 1967 (Insecta, Odonata, Corduliidae). Contribuições Avulsas sobre a História Natural do Brasil, Série Zoologia 32: 1-5.

Carvalho, A. L. \& J. L. Nessimian. 1998. Odonata do Estado do Rio de Janeiro, Brasil: hábitats e hábitos das larvas, p. 3-28. In: Nessimian, J. L. \& A. L. Carvalho (eds.). Ecologia de Insetos Aquáticos. Oecologia Brasiliensis vol. V. Rio de Janeiro, Programa de Pós-Graduação em Ecologia UFRJ, 309 p.

Carvalho, A. L.; A. P. Pinto \& N. Ferreira-Jr. 2009. Castoraeschna corbeti sp. nov. from Floresta Nacional de Carajás, Pará state, Brazil (Odonata: Aeshnidae). International Journal of Odonatology 12: 337-346, pl. VI.

Carvalho, A. L.; L. G. V. Salgado \& G. Fleck. 2008. Description of the larva of Lauromacromia picinguaba Carvalho, Salgado \& Werneck-deCarvalho 2004, with key to the genera of Corduliidae larvae occurring in South America. Zootaxa 1848: 57-65.

Carvalho, A. L.; L. G. V. Salgado, \& P. C. Werneck-de-Carvalho. 2004. Description of a new species of Lauromacromia Geijskes, 1970 
(Odonata: Corduliidae) from Southeastern Brazil. Zootaxa 666: 1-11. Clausnitzer, V.; V. J. Kalkman; M. Ram, B. Collen; J. E. M. Baillie; M. Bedjanič; W. R. T. Darwall; K. D. B. Dijkstra; R. Dow; J. Hawking; H. Karube; E. Malikova; D. Paulson; K. Schütte; F. Suhling; R. J. Villanueva; N. von Ellenrieder \& K. Wilson. 2009. Odonata enter the biodiversity crisis debate: The first global assessment of an insect group. Biological Conservation 142: 1864-1869.

Costa, C.; S. Ide; G. H. Rosado-Neto; M. H. M. Galileo; C. R. V. Fonseca; R. M. Valente \& M. A. Monné. 2000. Diagnóstico del conocimiento de las principales colecciones brasileñas de Coleoptera, p. 115-136. In: MartínPiera, F.; J. J. Morrone \& A. Melic (eds.). Hacia un Proyecto CYTED para el Inventario y Estimación de la Diversidad Entomológica en Iberoamérica: PrIBES-2000. vol. 1, Zaragoza, Monografías Tercer Milenio, $326 \mathrm{p}$.

Costa, J. M. \& A. B. M. Machado. 2007. Two new species of Neocordulia Selys, 1882 from southern Brazil (Anisoptera: Corduliidae). Lundiana 8: $143-146$.

Costa, J. M.; A. B. M. Machado; F. A. A. Lencioni \& T. C. Santos. 2000. Diversidade e Distribuição dos Odonata (Insecta) no Estado de São Paulo, Brasil: Parte I-Lista das Espécies e registros bibliográficos. Publicações Avulsas do Museu Nacional 80: 1-27.

Costa, J. M. \& B. J. A. Mascarenhas. 1998. Catálogo do material-tipo de Odonata (Insecta) do Museu Nacional. Publicações Avulsas do Museu Nacional 76: 1-30.

Costa, J. M. \& B. B. Oldrini. 2005. Diversidade e Distribuição dos Odonata (Insecta) no Estado do Espírito Santo, Brasil. Publicações Avulsas do Museu Nacional 107: 1-15.

Costa, J. M.; C. T. Ravanello \& G. M. Souza-Franco. 2008. Description of a new species of Neocordulia Selys, 1882 (Odonata: Libellulidae, Corduliinae) from southern Brazil. Zootaxa 1704: 64-68.

Costa, J. M \& T. C. Santos. 1992. Santosia marshalli gen. nov., spec. nov. - A new genus and species of Corduliinae from Brazil (Anisoptera: Cordullidae). Odonatologica 29: 95-111.

Costa, J. M \& T. C. Santos. 2000a. Two new species of Santosia Costa \& Santos, 1992, with a description of five new corduliid larvae (Anisoptera: Corduliidae). Odonatologica 29: 95-111.

Costa, J. M \& T. C. Santos. 2000b. Neocordulia mambucabensis spec. nov., new dragonfly from Rio de Janeiro Brazil. Odonatologica 29: 247-253.

Cowley, J. 1934. Notes on Odonata (Corduliidae) of the neotropical region. Stylops 3: 91-95.

De Marco, P. 1998. The Amazonian campina dragonfly Assemblage: Patterns in microhabitat use and behaviour in foraging habitat (Anisoptera). Odonatologica 27: 239-248.

De Marco, P. \& D. M. Vianna. 2005. Distribuição do esforço de coleta de Odonata no Brasil - subsídios para escolha de áreas prioritárias para levantamentos faunísticos. Lundiana 6(supplement): 13-26.

De Marmels, J. 1989. Odonata or dragonflies from Cerro de la Neblina and the adjacent lowland between the Rio Baria, the Casiquiare and the Rio Negro (Venezuela). I. Adults. Boletín de la Academia de las Ciências Físicas, Matemática y Naturales 25: 11-78.

De Marmels, J. 1991. Dorocordulia nitens sp. n., eine neue Smaragdlibelle aus Venezuela (Odonata: Corduliidae). Mitteilungen der Entomologischen Gesellschaft Basel 41: 106-111.

ESRI. 1999. ArcView ${ }^{\circledR}$ GIS 3.2a. New York. Environmental Systems Research Institute Inc.

Fleck, G.; G. Bechly; X. Martínez-Delclòs; E. Jarzembowski; R. Coram \& A. Nel. 2003. Phylogeny and classification of the Stenophlebioptera (Odonata: Epiproctophora). Annales de la Société Entomologique de France (Nouvelle série) 39: 55-93.

Fleck, G.; N. Hamada \& A. L. Carvalho. 2009. A remarkable new genus and species of dragonfly (Odonata: Anisoptera: Libellulidae) from Brazil and notes on its bionomics and phylogenetic affinities. Annales de la Société Entomologique de France (Nouvelle série) 45: 275-284.

Fleck, G. \& J. Legrand. 2006. La larve du genre Nesocordulia McLachlan, 1882, conséquences phylogénétiques [Odonata, Anisoptera, Corduliidae]. Revue Française d'Entomologie (Nouvelle-Série) 28: 31-40.

Garrison, R. W. 1991[2009]. A synonymic list of the New World Odonata. Argia 3: 1-30. [Updated version available at: http://www.odonatacentral.
org/views/pdfs/NWOL.pdf (accessed in 1 August 2009)]

Garrison, R. W.; N. von Ellenrieder \& J. A. Louton. 2006. Dragonfly genera of the New World: an illustrated and annotated key to the Anisoptera. Baltimore, The Johns Hopkins University Press, xiv+368 p.

Geijskes, D. C. 1970. Generic characters of the South American Corduliidae, with descriptions of the species found in the Guyanas. Studies on the Fauna of Suriname and other Guianas 12: 1-42, pls. I-II.

Heckman, C. W. 2006. Encyclopedia of South American aquatic insects: Odonata - Anisoptera. Illustrated keys to known families, genera, and species in South America. Dordrecht, Springer, viii+725.

Instituto Brasileiro de Geografia e Estatística (IBGE). 2007. Malha municipal digital do Brasil - 2005. Available at: http://www.ibge.gov. br/servidor_arquivos_geo/ (accessed in 10 October 2007).

Kalkman, V. J.; V. Clausnitzer; K. D. B. Dijkstra; A. G. Orr; D. R. Paulson \& J. van Tol. 2008. Global diversity of dragonflies (Odonata) in freshwater. Hydrobiologia 595: 351-363.

Longfield, C. 1929. A list of Odonata of the state of Matto Grosso, Brazil. Transactions of the Royal Entomological Society of London 77: $125-139$.

Machado, A. B. M. 2002. Description of Lauromacromia flaviae spec. nov., with notes on the holotype of L. luismoojeni (Santos) (Anisoptera: Corduliidae). Odonatologica 31: 313-318.

Machado, A. B. M. 2005a. Schizocordulia gen. nov. related to Aeschnosoma Selys with description of the female and additional data on the male Schizocordulia rustica (Selys) comb. nov. (Odonata, Corduliidae). Revista Brasileira de Zoologia 22: 775-779.

Machado, A. B. M. 2005b. Lauromacromia bedei sp. nov. do Estado de Minas Gerais, Brasil (Odonata, Corduliidae). Revista Brasileira de Entomologia 49: 453-456.

Machado, A. B. M. 2005c. Neocordulia matutuensis spec. nov. from Brazil (Anisoptera: Corduliidae). Odonatologica 34: 299-302.

Machado, A. B. M. \& J. M. Costa. 1995. Navicordulia gen. nov. a new genus of Neotropical Corduliidae, with descriptions of seven new species (Anisoptera: Corduliidae). Odonatologica 24: 187-218.

Martin, R. 1906. Cordulines. In: Catalogue Systématique et Descriptif des Collections Zoologiques Du Baron Edmond de Selys Longchamps. Fasc. 17, Bruxelles, Hayez, Impr. Des Académies, 94 p., pls. I-III.

May, M. 1991. A review of the genus Neocordulia, with a description of Mesocordulia subgen. nov. and of Neocordulia griphus spec. nov. from Central America, and a note on Lauromacromia (Odonata: Corduliidae). Folia Entomológica Mexicana 82: 17-67.

Morrone, J. J. 2006. Biogeographic areas and transition zones of Latin America and the Caribbean islands based on panbiogeographic and cladistic analyses of the entomofauna. Annual Review of Entomology 51: 467-94.

Pfau, H. K. 2005. Structure, function and evolution of the 'glans' of the anisopteran vesica spermalis (Odonata). International Journal of Odonatology 8: 259-310.

Pinto, A. P. \& A. L. Carvalho. 2010. A new species of Lauromacromia (Odonata: Corduliidae) from Southeastern Brazil, with a cladistic analysis of the genus and comments on Neotropical dragonfly biogeography. Zootaxa 2425: 45-68.

Riek, E. F. \& J. Kukalová-Peck. 1984. A new interpretation of dragonfly wing venation based upon Early Upper Carboniferous fossils from Argentina (Insecta: Odonatoidea) and basic character states in pterygote wings. Canadian Journal of Zoology 62: 1150-1116.

Santos, N. D. 1966. Odonatas da região de Poços de Caldas, Minas Gerais. Atas da Sociedade de Biologia do Rio de Janeiro 10: 65-69.

Santos, N. D. 1967a. <<Neocordulia luis-moojeni $>>$ sp. n. (Odonata, Corduliidae). Atas da Sociedade de Biologia do Rio de Janeiro 11: 113-115.

Santos, N. D. 1967b. Odonatas de Poços de Caldas MG. $-<<$ Neocordulia carlo-chagasi $>>$ sp. n. (Odonata: Corduliidae). Atas da Sociedade de Biologia do Rio de Janeiro 11: 81-82.

Santos, N. D. 1968a. Notas sobre $<<$ Dorocordulia errans $>>$ Calvert, 1909 (Odonata, Corduliidae). Atas da Sociedade de Biologia do Rio de Janeiro 11: 201-202.

Santos, N. D. 1968b. Notas sobre $<<$ Neocordulia androgynis $>>$ (Selys, 
1871) (Odonata, Corduliidae). Atas da Sociedade de Biologia do Rio de Janeiro 11: 147-148.

Santos, N. D. 1970. Odonatas de Itatiaia (Estado do Rio de Janeiro) da Coleção Zikan, do Instituto Oswaldo Cruz. Atas da Sociedade de Biologia do Rio de Janeiro 13: 203-205.

Santos, N. D. 1981. A new species of Aeschnosoma Selys, 1871 from Brazil, with new distributional records and notes $A$. forcipula Selys, 1871 (Corduliidae). Odonatologica 10: 43-47.

Vick, G. S. \& D. G. Chelmick. 2001. A preliminary report on the odonate fauna of Guapi Açu, a nature reserve in the Atlantic coast forest of Brazil. Opuscula Zoologica Fluminensia 200: 1-11.

von Ellenrieder, N. 2009. Databasing dragonflies: state of knowledge in the
Neotropical region. Agrion 13: 58-72.

von Ellenrieder, N. \& R. W. Garrison. 2008. The genus Oligoclada in Argentina, with description of $O$. rubribasalis sp. nov. (Odonata: Libellulidae). International Journal of Odonatology 11: 249-260.

Ware, J. L.; M. May \& K. Kjer. 2007. Phylogeny of the higher Libelluloidea (Anisoptera: Odonata): an exploration of the most speciose superfamily of dragonflies. Molecular Phylogenetics and Evolution 45: 289-310.

Ware, J. L.; J. P. Simaika \& M. J. Samways. 2009. Biogeography and divergence time estimation of the relict Cape dragonfly genus Syncordulia: global significance and implications for conservation. Zootaxa 2216: 22-36. 